\title{
Sieć boga Indry. W obronie integralności hinduizmu
}

\author{
Rajiv Malhotra, Ingra's Net. Defending Hinduism's Philosophical Unity, Harper \\ Collins, 2016, ss. 400.
}

$K^{s}$ siążka Rajiva Malhotry Indra's Net. Defending Hinduism's Philosophical Unity wpisuję się w żywą dyskusję nad statusem współczesnego hinduizmu. Autor występuje tu przeciw utartym, zachodnim sposobom naukowego ujmowania religijnej tradycji Indii i przedstawia perspektywę z wewnątrz pola badań. Tym samym książka ta wyraża postawę autora z innych jego publikacji, takich jak: The Battle for Sanskrit: Is Sanskrit Political or Sacred? Oppressive or Liberating? Dead or Alive?; Breaking India: Western Interventions in Dravidian and Dalit Faultlines; Being Different: An Indian Response to Western Universalism.

Jak sam tytuł wskazuje, autor stara się obronić jednolitość filozofii hinduskiej, posiłkując się znaną z tradycji indyjskiej metaforą „sieci boga Indry”. Metaforę tę można odnaleźć zarówno w pismach wedyjskich, jak i buddyjskich. Przedstawia ona zapisaną w naturze całego wszechświata współzależność wszystkich istniejących rzeczy. W odniesieniu do myśli indyjskiej metafora ta ma, w zamierzeniu autora, przedstawiać jednolitość filozofii i praktyk hinduizmu w oparciu o współdziałanie ze sobą wszystkich, pozornie odrębnych, jej elementów. Jest to wyraźnie wymierzone w przekonanie promowane przez wielu autorów na Zachodzie, że współczesny hinduizm jest systemem pozbawionym spójności, który został sztucznie stworzony na przestrzeni ostatnich około 150 lat. 
Autor przedstawia ów pogląd środowisk naukowych jako tezę o „neo-hinduizmie”, której rdzeniem jest twierdzenie, że religijne tradycje Indii nigdy nie wykazywały spójności, a współczesny hinduizm został opracowany przez Swamiego Vivekanandę (1863-1902) wskutek jego zetknięcia się z kulturą chrześcijańską Zachodu. Współczesny hinduizm (neo-hinduizm) ma być zatem tworem sztucznie unifikującym różne systemy religijne Indii. Swami Vivekananda, znany najbardziej ze swojego uczestnictwa w Światowym Parlamencie Religii w 1893 r., widziany jest tutaj w roli konstruktora nieistniejącego wcześniej systemu. Przypisywane jest mu czerpanie z myśli chrześcijańskiej i chęć nadania hinduizmowi statusu religii równej tym wywodzącym się z Zachodu, a także wzmocnienie nacjonalizmu indyjskiego przeciw brytyjskim kolonizatorom.

W pierwszej części książki (rozdziały 1-7) Rajiv Malhotra przedstawia kształtowanie się takiego poglądu na Zachodzie i jego przenikanie do różnych sfer, nie tylko filozoficznej, ale także społecznej i politycznej. W rozdziale pierwszym autor omawia podstawowe mity na temat hinduizmu, które jego zdaniem muszą zostać poddane rewizji, m.in. twierdzenia, że rozdrobnienie było zawsze naturalnym stanem Indii, hinduizm został skonstruowany albo że to społeczna etyka Zachodu stała się podstawą koncepcji hinduskich, takich jak „seva” i „karma-joga”. W kolejnych rozdziałach autor przedstawia konkretne prace i osoby, które przyczyniły się do propagacji owych mitów. Pojawiają się tu m.in. nazwiska takie jak Paul Hacker, Anantanand Rambachan, Ursula King czy Agehananda Bharati. Ten ostatni, opisując stan współczesnego hinduizmu, posługuję się metaforą „efektu pizzy”. Zgodnie z nią obecna religia hinduska została wzbogacona o wiele elementów, wcześniej z nią niezwiązanych (jak to miało miejsce w przypadku pizzy, gdy trafiła z Włoch do Ameryki). Metafora ta pokazuje, że hinduizm to w zasadzie współczesny konstrukt, który podjął pewne stare tradycje i zreorganizował je w nowy produkt. Tym samym powiela się również błędną według Rajiva Malhotry tezę, że hinduizm zapożyczył wiele idei od świata Zachodu, których nie był w stanie sam wytworzyć w swoich ramach. Jak wskazuje autor, wiele z założeń „tezy neo-hinduizmu” zostało opracowanych przez ludzi Zachodu, którzy przyjęli w swoim życiu hinduskie praktyki duchowe. Niestety to właśnie ich zachodnie rozumienie hinduizmu miało wpływ na kształtowanie się ich twierdzeń, co odbiło się źle na samej tradycji.

W części drugiej (rozdziały 8-12) autor kontrastuje opisane w części pierwszej poglądy z jego własnymi argumentami przeciw utrzymywaniu, że hinduizm nie był nigdy spójnym systemem i został skonstruowany przez Swamiego Vivekanandę. Po pierwsze wskazuje, że idee proponowane przez Vivekanandę były mocno ugruntowane w tradycji hinduizmu długo przed czasami kolonialnymi. Ponadto pozorne rozdrobnienie i niespójność religii jest w istocie wyrazem jej otwartości i uznania wielu sposobów wyrażania się zarówno religijnego, jak i filozoficznego. W sukurs przychodzi tu tytułowa „sieć Indry”, która ma metaforycznie odzwierciedlać złożoność i współzależność całości tradycji. Autor trafnie wskazuje tak- 
że, że praktyka jogi oraz filozofia Wedanty nie są wcale niezależnymi od siebie systemami, a wzajemnie się uzupełniają. Udowadnia również, że idea pracy dla społeczeństwa istniała w hinduizmie, zanim ten zetknął się z etyką chrześcijańską, co osłabia tezę o wpływie chrześcijaństwa na ukształtowanie się współczesnej etyki hinduskiej. Wszystko to prowadzi autora do podtrzymania swojej tezy o inherentnej integralności hinduizmu.

Do tego celu Rajiv Malhotra posługuje się dwoma terminami: „otwarta architektura” i „integralna jedność”. Pierwsze z nich wskazuje, że w odróżnieniu od systemów zachodnich hinduizm zawsze wykazywał elastyczność i adaptowalność do odpowiednich warunków historycznych i społeczno-kulturowych. Drugie zaś wskazuje, że pomimo tej otwartości zachowuje on spójność i jedność. To zachowanie balansu pomiędzy tymi dwoma aspektami wyróżnia hinduizm na tle współczesnych systemów religijnych, które z reguły, zdaniem autora, zachowują jedność kosztem otwartości. Dlatego też zachodniemu umysłowi jest tak trudno zrozumieć złożoność hinduizmu. Przykładem może tu być położenie nacisku na drugi koniec spektrum, jak w przypadku ruchów New Age, które przyjmują radykalną otwartość, poświęcając tym samym jedność i spójność. W obu przypadkach zachodnia kultura religijna i duchowa odbiega od tej, którą można spotkać w hinduizmie. Ludzie zachodu i zwesternizowani wyznawcy hinduizmu są niestety często winni patrzenia na tą religię poprzez pryzmat radykalnej otwartości, a tym samym niejednolitości i niespójności.

Ponadto, zarówno w pierwszej, jak i drugiej części książki autor wskazuje na istotne braki w podejściu zachodnich akademików do problematyki hinduizmu. Trafnie zauważa, że bardzo często dokonuje się tu zbyt wielkich uproszczeń. Przykładowo myśl filozoficzna Indii jest widziana niemal wyłącznie przez pryzmat Adwajta Wedanty, wyłożonej przez Śankarę (788-820). Zapomina się tu o innych bardzo wpływowych systemach filozoficznych, jak Wiśiszta Advajta Wedanta Ramanudźy (1017-1137) czy Dwajta Wedanta Madwy (1238-1317).

Inną kwestią, na którą autor zwraca dużą uwagę, jest fakt, że wiele koncepcji wywodzących się z hinduizmu przeniknęło do różnych sfer życia na Zachodzie bez właściwego uznania ich pochodzenia. Wiele teorii naukowych czerpie z wiedzy Wschodu. Rajiv Malhotra wskazuje przykładowo na nauki kognitywne, które przez lata niepostrzeżenie wchłonęły koncepcje wywodzące się z hinduizmu. Brak jest tu natomiast, zdaniem autora, uczciwego uznania autorstwa owych koncepcji, które zostały przyswojone. Dlatego też Rajiv Malhotra podsumowuje swoje rozważania, przedstawiając metaforę „przetrawienia” koncepcji znajdujących się w hinduizmie przez kulturę Zachodu, zarówno religijną, jak i sekularną. Przetrawienie polega na wzięciu pojedynczego aspektu hinduizmu i zintegrowanie go z rodzimymi dla „trawiącego” ideami. W tym kontekście można wskazać wiele aspektów dharmicznych religii, takich jak hinduizm i buddyzm, które na dobre zadomowiły się na Zachodzie, ale jednocześnie zostały odcięte od swoich korzeni. Przykładami 
mogą tu być chociażby praktyka jogi i medytacji. Obie te rzeczy są przyjmowane przez wielu ludzi na Zachodzie jako część codziennego życia. Niestety, jak zwraca uwagę Rafiv Malhotra, odbywa się to kosztem integralności tradycji, z których owe praktyki zostały zaczerpnięte i niejednokrotnie zapomina się o ich pochodzeniu, instrumentalnie wykorzystując je w ramach kultury zachodniej. W ten sposób religie takie jak hinduizm i buddyzm zostają przetrawione, co niestety skutkuje utratą ich właściwej natury na rzecz zintegrowania ich w system „drapieżnika”. Teza „neo-hinduizmu” ukuta w kręgach zachodnich świetnie, według autora, się do tego celu nadaje. Wielu wyznawców hinduizmu może być zadowolonych z faktu, że ich rodzime praktyki są przyjmowane na Zachodzie, jednak dzieje się to kosztem redukcji ich tradycji do kilku luźno powiązanych ze sobą aspektów.

Aby uniknąć przetrawienia, autor publikacji przedstawia strategię „trujących pigułek”, które mają uniemożliwić przetrawienie hinduizmu na Zachodzie. Określenie „trująca pigułka” odnosi się do założeń ideowych hinduizmu, które nie mogą zostać zintegrowane z ideologiami Zachodu. A gdyby takie zintegrowanie miało miejsce, cały system myślowy Zachodu musiałby równolegle ulec zmianie. „Trującymi ideami” trudnymi do przetrawienia zarówno przez religie zachodnie, jak i sekularyzm zachodni są, według autora, przede wszystkim koncepcje reinkarnacji, karmy i ucieleśnionej wiedzy. Uważny obserwator życia społecznego na Zachodzie może zauważyć, że te właśnie koncepcje są często odrzucane jako niepasujące do zachodniego światopoglądu. Wielu ludzi może praktykować jogę i medytacje, jednocześnie nie przyjmując bądź podchodząc agnostycznie do podstawowych idei filozoficznych, które były zawsze związane z tymi praktykami. Tym samym koncepcja Rajiva Malhotry staje się wyzwaniem rzuconym ludziom Zachodu, zarówno intelektualistom, jak i pospolitym zjadaczom chleba, aby adaptowali praktyki i idee hinduizmu z przysłowiowym „dobrodziejstwem inwentarza”, nie zaś rozdrabniali je według swoich potrzeb.

Z innej strony (zrozumiałej z punktu widzenia autora) można wskazać na indiocentryzm książki. Autor zdaje się skupiać na hinduizmie jako tradycji przede wszystkim indyjskiej, zamkniętej w określonych geograficznych i etnicznych granicach. Ostatnimi laty pojawiły się jednak głosy, aby traktować hinduizm jako światopogląd bardziej uniwersalny ${ }^{1}$. Rozumie się przez to, że idee dharmiczne, które dzisiaj można odnaleźć głównie we współczesnym hinduizmie i buddyzmie, były w odległej starożytności podzielane, w większym lub mniejszym stopniu, przez wszystkie ludy na Ziemi. Przykładem mogą tu być chociażby pisma starożytnych Greków i Rzymian, które odwołują się do uniwersalnych praw rządzących istnieniem. Ponadto zauważa się, że nazwa hinduizm jako skonstruowana na Zachodzie, nie jest odpowiednią nazwą tej tradycji. Zamiast niej postuluje się używanie bardziej adekwatnej nazwy „Sanatana Dharma”, która oznacza „Od-

${ }^{1}$ Zob. Sri Dharma Pravartaka Acharya, Sanatana Dharma: The Eternal Ntural Wau, ISDS, Omaha 2015. 
wieczną Naturalną Drogę”. Nazwa ta w odróżnieniu od słowa „hinduizm” jest często spotykana w starożytnych, wedyjskich pismach jako właściwe określenie tej tradycji. Rajiv Malhotra uznaje to określenie, jednakże dla wygody pozostaje przy nazwie hinduizm. Może to dziwić, zważywszy na ton i charakter całej publikacji, w której autor żywo krytykuje westernizację tradycji Indii, jednak pozostaje przy kolonialnym określeniu hinduizm. Sprawia to, że w oczach czytelnika temat zostaje zawężony do problemu samych Indii i wyznawców Sanatana Dharmy wywodzących się z tego kraju. Określenie Sanatana Dharma natomiast wskazuje, że nie jest to tradycja będąca dziedzictwem Indii, lecz można ją rozpatrywać jako dziedzictwo globalne, odwołujące się do uznania uniwersalnych, metafizycznych zasad rządzących stworzeniem.

Mimo to książka Rajiva Malhotry stanowi dobre wprowadzenie dla każdego, kto chce zrozumieć problemy współczesnego hinduizmu. Doskonale przedstawia napięcie między westernizacją koncepcji zawartych w tej tradycji a próbą zachowania jej autentyczności. Jest niezwykle ważną pozycją w obecnym dyskursie prowadzonym wokół współczesnych religii.

\section{O autorze}

Rajiv Malhotra jest indyjskim intelektualistą i działaczem społecznym zaangażowanym w utrzymywanie i ochronę rodzimej kultury Indii. Jest odważnym orędownikiem integralności religijnej współczesnego hinduizmu. W wieku 44 lat rzucił karierę zawodową i założył Infinity Fundation. Obecnie jest autorem wielu publikacji, które kwestionują współczesne podejście do Indii i hinduizmu. Jest również bardzo aktywny jako mówca. Wykładał w wielu miejscach na świecie, m.in. w brytyjskim parlamencie. Dla wsparcia swojej działalności otworzył kanał na Youtubie „Rajiv Malhotra Official”, gdzie aktywnie odnosi się do współczesnych problemów Indii i hinduizmu. 
